\title{
Pengaruh Konseling Qur'ani Untuk Menurunkan Tingkat Depresi Pada Mahasiswa
}

\author{
Shanty Komalasari \\ Universitas Islam Negeri (UIN) Antasari
}

\begin{abstract}
This research aims to know the difference between the experimental group given intervention with Quranic counseling and a control group without intervention. This is quasi-experimental research that used untreated control group design with pretest and posttest. The subjects of this research were 20 students of UIN Antasari Banjarmasin that have passed the screening test. They were divided into an experimental group and control group, each of which consisted of 10 people. After the data were analyzed using non-parametric Mann-Whitney test, it was found out that = - 1553; sig = $0.121(p>0,05)$, which means there was no significant difference between the level of depression on students in the experimental group after the intervention and the level of depression on students in control group. Afterward, according to the analysis result on Wilcoxon score in the post-test and interview by the experimental group, it was found out that $Z$ score $=-0,609$ a and $p$ score $=0,542$; therefore, $p>0,05$. It means Quranic counseling is relatively effective to decrease the level of depression on the students. Despite there was no significant difference between the experimental group and control group, the depression level on the experimental group, however, did not increase even though the Quranic counseling had been given over two weeks before.
\end{abstract}

Keywords: Depression; Qur'anic counseling; students

\begin{abstract}
Abstrak
Penelitian ini bertujuan untuk mengetahui perbedaan antara kelompok eksperimen yang diberikan intervensi dan kelompok kontrol yang tidak diberikan intervensi konseling Qur'ani, serta mengetahui efektivitas intervensi konseling Qur'ani. Penelitian ini merupakan penelitian kuasi eksperimen dengan desain untreated control group design with pretest and posttest. Subjek dalam penelitian ini adalah 20 orang mahasiswa UIN Antasari Banjarmasin yang telah di screening test. Mereka dibagi menjadi kelompok eksperimen dan kontrol yang masing-masing terdiri dari 10 orang. Setalah dilakukan analisis data menggunakan uji non parametrik MannWhitney diketahui bahwa $Z=-1553$; sig $=0.121(\mathrm{p}>0,05)$ yang berarti bahwa tidak adanya perbedaan tingkat depresi pada mahasiswa antara kelompok eksperimen setelah diberikan intervensi dan kelompok kontrol yang tidak diberiikan intervensi. Kemudian menurut hasil analisis uji Wilcoxon skor post test dan wawancara pada kelompok eksperimen diperoleh skor Z $=-0,609^{a}$ dan skor $p=0,542$ sehingga $p>0,05$ yang berarti bahwa konseling Qur'ani dapat dikatakan cukup efektif untuk menurunkan tingkat depresi pada mahasiswa. Karena walaupun tidak terdapat perbedaan yang signifikan antara kelompok eksperimen dan kelompok kontrol namun pada kelompok eksperimen diketahui bahwa tingkat depresi pada mahasiswa tidak menunjukkan kenaikan meskipun konseling Qur'ani telah diberikan lebih dari dua minggu.
\end{abstract}


Kata Kunci: Depresi; Konseling Qur'ani; Mahasiswa

Depresi kini sudah tidak asing lagi bagi masyarakat karena dapat menyerang seluruh usia dan lapisan masyarakat. Depresi merupakan problem kesehatan masyarakat yang bisa dikatakan cukup serius (Larastiti, Fitrikasari, \& AS, 2014). Dalam World Health Organization (WHO) disebutkan bahwa depresi berada pada urutan keempat penyakit di dunia (Nurmiati, 2005). Kemudian didukung oleh hasil survei di 14 negara pada tahun 1990 yang menyebutkan bahwa depresi merupakan masalah kesehatan dengan urutan ke-4 terbesar di dunia yang mengakibatkan beban sosial pada masyarakat. Bahkan WHO juga mempredikasikan bahwa 2 tahun yang akan datang yakni pada tahun 2020 depresi akan menjadi penyebab penyakit kedua setelah penyakit kardiovaskular (Hariyanto, 2010). Adapun di Indonesia prevelensi depresi cukup tinggi, yakni sekitar 17-27\%. Prevalensi depresi di dunia diperkirakan $5-10 \%$ per tahun (Larastiti dkk., 2014).

Depresi adalah gangguan kejiwaan pada alam perasaan yang ditandai dengan munculnya perilaku seseorang yang tidak biasanya seperti murung, tidak ada gairah hidup, merasa tidak berguna, patah semangat, atau kesedihan yang bisa jadi menandakan adanya gangguan kesehatan bahkan sampai pikiran tentang kematian dan keinginan bunuh diri (Hawari, 2010). Dalam American Psychiatric Association mengungkapkan bahwa seseorang dapat dikatakan menderita gangguan depresi jika mengalami lima atau lebih gejala depresi, kemudian gejala tersebut telah ada selama periode dua minggu dan merupakan perubahan dari keadaan biasa seseorang (American Psychiatric Association, 2000). Selanjutnya dalam DSM IV tersebut juga mengatakan bahwa karakteristik individu yang mengalami depresi berkaitan dengan mood yang selalu merasa sangat sedih, minat atau keinginan yang hampir setiap hari menurun, pengurangan atau peningkatan pola makan sebanyak 5\% dalam per-bulannya atau rasa lapar akan sangat menurun atau meninggi setiap harinya, hampir setiap hari individu tidur dalam waktu yang sangat lama, hampir setiap hari pula individu akan terlihat sangat aktif atau sebaliknya aktivitasnya sangat menurun drastis, individu pun akan terlihat lelah atau kehilangan energi hampir setiap hari, biasanya individu juga hampir setiap hari akan merasa dirinya tidak berharga atau merasa bersalah terhadap sesuatu hal yang tidak diketahuinya, 
individu pun hampir setiap hari akan mengalami kesulitan atau bermasalah dengan pikirannya untuk menentukan sesuatu atau tidak mampu berkonsentrasi, mereka juga akan terus menerus berpikir tentang kematian atau tentang bunuh diri dengan atau tanpa rasa sakit, atau telah mencoba untuk melakukan bunuh diri (Morrison, 1995).

Berdasarkan data yang dihimpun Centers for Disease Control and Prevention (CDC) pada tahun 2007-2010, prevalensi depresi paling tinggi diderita oleh kelompok usia 40-59 tahun, yakni sebesar 9,45\%. Kemudian, angka tertinggi kedua diperoleh oleh kelompok usia 18-39 tahun, yakni sebesar 8\%, selanjutnya disusul dengan kelompok usia 12-17 tahun sebesar 6,3\%. Usia yang dirasa ideal seseorang memasuki perguruan tinggi adalah 2 kelompok terakhir atau biasanya termasuk dalam kategori remaja akhir yaitu usia 17-21 (Larastiti dkk., 2014).

Hal ini semakin dikuatkan oleh Peluso yang menyatakan bahwa mahasiswa perguruan tinggi merupakan salah satu kelompok yang berisiko tinggi mengalami depresi dan gangguan emosional. Mahasiswa adalah kelompok khusus yang sedang berada dalam periode transisi kritis dari fase remaja ke dewasa awal yang kemudian dapat menjadi kelompok paling depresif dalam kehidupan seseorang. Peluso juga menyebutkan bahwa gejala depresi pada mahasiswa dapat mempengaruhi proses pembelajaran serta akan berakibat kurang baik terhadap performa akademik (Yorika, 2016).

Menurut hasil studi pendahuluan yang dilakukan oleh peneliti sebelum melakukan penelitian ini terhadap 5 mahasiswa, dari hasil wawancara tersebut diketahui bahwa banyak mahasiswa UIN Antasari Banjarmasin yang memiliki simtom-simtom depresi. Simtom atau gejala yang muncul dalam waktu bersamaan antara lain merasa tertekan, kehilangan minat dari aktivitas biasa yang dilakukan, turun berat badan, mengalami insomnia, merasa kelelahan, penurunan konsentrasi yang drastis dan ada terbersit keinginan bunuh diri. Simtom ini sesuai dengan gejala yang dikemukakan oleh Keltner dkk dan dalam DSM V. Menurut Reifman dan Dunkel-Schetter simtom depresi dan kecemasan menjadi perhatian khusus pada mahasiswa dan dihubungkan dengan performansi akademik yang rendah dan partisipasi rendah dalam aktivitas kampus. Oleh karena itu, kurangnya pengetahuan tentang cara mengatasi masalah depresi akan menyebabkan kejadian depresi yang lebih besar. Depresi pada mahasiswa dalam 
proses perkuliahan memang merupakan suatu fenomena yang harus diantisipasi, karena depresi itu sendiri ialah keadaan psikologis yang patologis (Larastiti dkk., 2014).

Berdasarkan pemaparan tersebut dapat disimpulkan bahwa depresi pada mahasiswa merupakan gangguan yang perlu dicermati dan diberikan penanganan yang serius. Sejauh ini penanganan depresi dapat dilakukan dengan tiga cara utama yaitu biologis, dengan obat anti depresan dan ECT atau Elecroconvulsive. Kemudian psikoterapi dan konseling psikologis, serta pelatihan-pelatihan. Ketiga cara utama itu seringkali dipakai oleh para ahli secara terpisah atau dengan mengkombinasikannya (Brannon \& Nelson, 1987).

Sebagai salah satu media komunikasi Allah Swt kepada manusia, Al-Qur'an merupakan kitab pedoman yang paling lengkap bahkan sangat memahami eksistensi manusia di dunia ini, sebagaimana Firman-Nya dalam Al-Qur'an surat Al-Baqarah ayat 185:

Artinya: (Beberapa hari yang ditentukan itu ialah) bulan Ramadhan, bulan yang di dalamnya diturunkan (permulaan) Al Quran sebagai petunjuk bagi manusia dan penjelasan-penjelasan mengenai petunjuk itu dan pembeda (antara yang hak dan yang bathil). Karena itu, barangsiapa di antara kamu hadir (di negeri tempat tinggalnya) di bulan itu, maka hendaklah ia berpuasa pada bulan itu, dan barangsiapa sakit atau dalam perjalanan (lalu ia berbuka), maka (wajiblah baginya berpuasa), sebanyak hari yang ditinggalkannya itu, pada hari-hari yang lain. Allah menghendaki kemudahan bagimu, dan tidak menghendaki kesukaran bagimu. Dan hendaklah kamu mencukupkan bilangannya dan hendaklah kamu mengagungkan Allah atas petunjuk-Nya yang diberikan kepadamu, supaya kamu bersyukur

Al-Qur'an adalah sebuah kitab suci yang diturunkan Allah Swt. sebagai petunjuk untuk umat Islam dan seluruh umat manusia pada umumnya. Di dalam Al-Qur'an banyak terdapat sumber-sumber keilmuan yang dapat digunakan untuk keperluan manusia di muka bumi ini. Keilmuan tersebut meliputi, petunjuk hidup, cara beribadah, cara bergaul sesama manusia dan sekitarnya seperti hewan dan tumbuhan, cara melangsungkan kehidupan di dunia seperti bermu'amalah, penerapan hukum yang ada di dunia dan merawat diri. Muhammad Ustman Najati berpendapat bahwa Al-Qur'an diturunkan untuk mengubah pikiran manusia, kecenderungannya dalam berperilaku dan tingkah lakunya, serta memberi petunjuk pada mereka, mengarahkan mereka kepada sesuatu yang baik dan membekali mereka dengan pikiran-pikiran baru tentang bagaimana tabiat manusia yang seharusnya (Najati, 2005). 
Selain itu dalam ayat Al-Qur'an yang lain disebutkan juga bahwa di dalam Al-Qur'an banyak sekali ayat yang mengandung nilai konseling. Allah memberikan kemudahan bagi orang yang mau mempelajari ayat-ayat Alquran. Seperti Firman Allah swt dalam Surat AlQamar (54) ayat 40 berikut ini:

Artinya: Dan sesungguhnya telah Kami mudahkan Al Quran untuk pelajaran, maka adakah orang yang mengambil pelajaran

Dari ayat di atas telah disebutkan bahwa Allah telah menurunkan Al-Qur'an untuk diambil sebagai pelajaran. Artinya Al-Qur'an dapat dijadian sebagai media yang akan membantu menyelesaikan permasalahan seseorang. Konseling Qur'ani dapat dilakukan sebagai metode untuk meningkatkan kesehatan mental karena Al-Qur'an dapat membantu seseorang untuk menemukan makna dalam kehidupannya. Seperti hasil dari penelitian Bastaman yang mengungkapkan bahwa untuk meraih kebahagiaan manusia perlu menemukan makna dalam setiap aktivitas kehidupannya, salah satu caranya adalah dengan menghayati dan mengamalkan ibadah, shalat, dzikir, doa, puasa, zakat infak shadaqah, haji, umrah serta mengkaji Al-Qur'an dan maknanya (Ekayani, 2018).

Ayat lain yang mengungkapkan tentang makna Al-Qur'an sebagai petunjuk adalah Surah An-Nahl ayat 89 yang artinya: (Dan ingatlah) akan hari (ketika) Kami bangkitkan pada tiaptiap umat seorang saksi atas mereka dari mereka sendiri dan Kami datangkan kamu (Muhammad) menjadi saksi atas seluruh umat manusia. Dan Kami turunkan kepadamu Al Kitab (Al Quran) untuk menjelaskan segala sesuatu dan petunjuk serta rahmat dan kabar gembira bagi orang-orang yang berserah diri

Al-Qur'an juga menjelaskan tentang makna dan tujuan kehidupan manusia selama berada di dunia ini, yaitu untuk beribadah, untuk menghadapi ujian, untuk meraih kehidupan akhirat yang lebih baik dan menyadari bahwa dunia ini besifat sementara. Berdasarkan paparan yang telah diberikan maka peneliti merancang sebuah model intervensi menggunakan pendekatan integrasi Ilmu Psikologi dan Islam yaitu konseling Qur'ani.

Konseling Qur'ani menurut Budiharto adalah proses konseling dengan berpedoman pada Firman Allah Swt dalam Al-Qur-an (Budiharto \& Anggraini, 2007). Konseling Qur'ani juga dapat diartikan sebagai upaya membantu individu belajar mengembangkan fitrah dan 
atau kembali kepada fitrah, dengan cara memberdayakan (empowering) iman, dan kemauan yang dikaruniakan Allah Swt kepadanya untuk mempelajari tuntunan Allah dan Rasul-Nya, agar fitrah yang ada pada individu itu berkembang dengan benar dan kokoh sesuai tuntunan Allah Swt. Seperti yang telah kita ketahui juga bahwa dalam Al-Qur'an terdapat banyak kandungan nilai seperti tentang keimanan, ibadah, ilmu pengetahuan, tentang kisah-kisah tertentu, filsafat, dan juga ada sebagai tata hubungan manusia sebagai makhluk individu maupun makhluk sosial.(Najati, 2005) Kandungan dalam Al-Qur'an diharapkan mampu menjadi motivasi dan penyemangat bagi mahasiswa yang mengalami gejala depresi.

Tujuan utama dalam proses konseling ini adalah menumbuhkan sikap konsisten terhadap arah ajaran agama Islam, selain itu juga bertujuan agar manusia memiliki kesadaran mengenai eksistensi dirinya dan bekerja untuk memperjuangkan hal tersebut. Pengembangan kemampuan manusia sehingga dapat menjalankan tanggung jawabnya selama kehidupan ini dan membentuk nilai dan kecendrungan positif sehingga dapat mengendalikan dan mengatur perilaku dan interaksi terhadap sesama manusia juga dapat dilakukan melalui konseling Islami (Adz-Dzakiey, 2006).

Konseling Qur'ani dalam penelitian ini merupakan kegiatan penggalian emosi, identifikasi permasalahan diri dan proses penyelesaian permasalahan dengan menggunakan Al-Qur'an. Penumbuhan keyakinan bahwa segala permasalahan dapat diselesaikan melalui AlQur'an. Al-Qur'an dianggap sebagai terapi yang sangat utama, karena di dalamnya memuat resep-resep mujarab yang dapat menyembuhkan penyakit jiwa manusia. Al-Qur'an diharapkan dikemudian hari agar tidak hanya dimaknai sebagai kitab suci umat muslim tetapi juga dimaknai sebagai sebuah pedoman yang di dalamnya terdapat segela hal baik yang selalu diusahakan perwujudannya dalam kerhidupan sehari-hari (Aziz, t.t.).

Tujuan dari penelitian ini adalah untuk mengetahui perbedaan antara kelompok eksperimen yang diberikan intervensi dan kelompok kontrol yang tidak diberikan intervensi, serta untuk mengetahui efektivitas pelatihan konseling Qur'ani. 


\section{Metode}

Jenis penelitian yang digunakan adalah jenis eksperimen dan pemilihan sampel dalam penelitian adalah dengan teknik sampel kuota. Pada penelitian ini, responden yang memenuhi kriteria dikelompokkan menjadi dua kelompok, kelompok intervensi dan kelompok kontrol. Pada kedua kelompok dilakukan pretest dengan menggunakan Beck Depression Inventory (BDI) untuk menentukan tingkat depresi sebelum intervensi. Pada kelompok eksperimen diberikan intervensi konseling Qur'ani sebanyak 4 jam 45 menit efektif yang terdiri dari beberapa sesi.

Berikut rancangan eksperimen yang akan dilakukan:

Tabel 1

Rancangan Eksperimen

\begin{tabular}{cccc}
\hline Kelompok & Pra & Intervensi & Pasca Intervensi \\
\hline Eksperimen & Y1 & $X$ & Y2 \\
Kontrol & Y1 & - & Y2 \\
\hline
\end{tabular}

\section{Keterangan:}

Y1 : Pengukuran sebelum diberi intervensi

Y2 : Pengukuran segera sesudah diberi intervensi

X : Intervensi

Dalam penelitian ini diungkap variabel bebas yaitu konseling qur'ani dan satu variabel terikat, yaitu depresi. Jumlah subjek sebanyak 20 mahasiswa yang memiliki kategori depresi (sedang sampai berat) pada skor BDI. Subjek penelitian ini adalah mahasiswa Universitas Islam Negeri Antasari Banjarmasin, usia antara 19-23, jenis kelamin laki-laki dan perempuan, bersedia mengikuti sesi konseling. Subjek dibagi ke dalam 2 kelompok yaitu kelompok eksperimen dan kelompok kontrol. Kelompok eksperimen adalah kelompok yang mendapatkan intervensi konseling Qur'ani. Kelompok kontrol adalah kelompok yang tidak mendapatkan intervensi konseling Qur'ani. Kelompok kontrol diperlakukan sebagai waiting-list, sehingga akan mendapatkan ientervensi pada waktu yang akan ditentukan kemudian.

Metode pengumpulan data yang digunakan dalam penelitian ini adalah Beck Depression Inventory (BDI), dan wawancara. Analisis kuantitatif yang digunakan dalam penelitian ini 
adalah uji non parametris Mann Whitney U Test. Uji ini digunakan untuk mengetahui perbedaan median 2 kelompok bebas apabila skala data variabel terikatnya adalah ordinal atau interval/ratio tetapi tidak berdistribusi normal dengan menggunakan IBM SPSS Statistics 21.0. Selain itu, pada penelitian ini juga menggunakan analisis kualitatif sebagai analisis pendukung berupa data wawancara yang dilakukan oleh narasumber dan peserta.

\section{Prosedur Penelitian}

Prosedur penelitian ini dilakukan dengan screening test, pretest, posttest, dan wawancara. Tahap pertama diawali dengan screening test, yakni pemberian alat ukur depresi berupa Beck Depression Inventory (BDI) dengan tujuan mengetahui tingkat depresi pada mahasiswa. Screening test dilakukan pada 80 orang subjek, ini didasarkan pada teknik pengambilan sampel yaitu Sampel kuota. Sampel kuota adalah teknik untuk menentukan sampel yang mempunyai ciri-ciri tertentu sampai jumlah (kuota) yang diinginkan (Sugiyono, 2017).

\section{Hasil}

Setelah melaksanakan screening test, selanjutnya melakukan kategorisasi data penelitian berdasarkan hasil skor BDI. Hasil skor tingkat depresi pada mahasiswa sebagai berikut:

Tabel 2

Kategori Tingkat Depresi Mahasiswa

\begin{tabular}{ccccc}
\hline No. & Skor & F & $\%$ & Kategori \\
\hline 1 & $0-9$ & 40 & 50 & Tidak ada gejala \\
2. & $10-15$ & 19 & 23,75 & Depresi Ringan \\
3. & $16-23$ & 18 & 22,5 & Depresi Sedang \\
4. & $24-63$ & 3 & 3,75 & Depresi Berat \\
\multicolumn{2}{c}{ Jumlah } & 80 & & 100 \\
\hline
\end{tabular}

Tahap selanjutnya adalah pretest, pretest pada penelitian adalah data yang diambil dari data screening test. Dari 80 mahasiswa dapat diambil untuk diintervensi atau diberikan intervensi adalah mahasiswa yang masuk kategori depresi ringan, sedang dan berat. Sehingga subjek yang diambil oleh peneliti berjumlah 20 orang, lalu dibagi dalam dua kelompok, yaitu 
kelompok eksperimen dan kelompok kontrol. Kelompok eksperimen berjumlah 10 orang dan kelompok kontrol berjumlah 10 orang.

Tabel 3

Skor Pretest Tingkat Depresi Kelompok Eksperimen

\begin{tabular}{cccc}
\hline Kelompok & Subjek & Skor pretest & Kategori \\
\hline \multirow{5}{*}{ Ekperimen } & $\mathrm{A}$ & 12 & Depresi Ringan \\
& $\mathrm{B}$ & 13 & Depresi Ringan \\
& $\mathrm{C}$ & 22 & Depresi Sedang \\
& $\mathrm{D}$ & 16 & Depresi Sedang \\
& $\mathrm{E}$ & 16 & Depresi Sedang \\
& $\mathrm{F}$ & 22 & Depresi Sedang \\
& $\mathrm{G}$ & 15 & Depresi Ringan \\
& $\mathrm{H}$ & 17 & Depresi Sedang \\
& $\mathrm{I}$ & 22 & Depresi Sedang \\
& $\mathrm{J}$ & 16 & Depresi Sedang \\
\hline
\end{tabular}

Dari tabel 3 dapat diketahui skor pretest Kelompok Eksperimen. Skor terendah 12 dan skor tertinggi 22. Dari 10 subjek diketahui ada 3 orang yang berada pada kategori depresi ringan dan ada 7 orang yang berada dikategori sedang. Hal ini menunjukkan bahwa pada Kelompok Eksperimen rata-rata subjek penelitian berada pada kategori depresi ringan dan sedang.

Tabel 4

Hasil Skor Pretest Tingkat Depresi Kelompok Kontrol

\begin{tabular}{cccc}
\hline Kelompok & Subjek & Skor pretest & Kategori \\
\hline Kontrol & $\mathrm{K}$ & 11 & Depresi Ringan \\
& $\mathrm{L}$ & 16 & Depresi Sedang \\
$\mathrm{M}$ & 24 & Depresi Berat \\
& $\mathrm{N}$ & 12 & Depresi Ringan \\
$\mathrm{O}$ & 12 & Depresi Ringan \\
& $\mathrm{P}$ & 10 & Depresi Ringan \\
& $\mathrm{Q}$ & 20 & Depresi Sedang \\
$\mathrm{R}$ & 14 & Depresi Ringan \\
& $\mathrm{S}$ & 10 & Depresi Ringan \\
& $\mathrm{T}$ & 11 & Depresi Ringan \\
\hline
\end{tabular}


Dari tabel di atas dapat diketahui skor pretest Kelompok Kontrol. Skor terendah 10 dan skor tertinggi 24. Dari 10 subjek diketahui ada 7 orang yang berada pada kategori depresi ringan, kemudian ada 2 orang yang berada pada kategori depresi sedang dan 1 orang berada pada kategori depresi berat. Hal ini menunjukkan bahwa pada Kelompok Kontrol subjek penelitian berada pada kategori depresi ringan, sedang dan berat.

Setelah dilakukan pretest, maka tahapan selanjutnya adalah pelaksanaan pelatihan konseling Qur'ani. Pelatihan konseling Qur'ani dilakukan selama satu hari dengan total waktu efektif 4 jam 30 menit. Pelatihan diberikan oleh seorang narasumber dan dibantu oleh 3 orang observer. Penelitian ini dilaksanakan disalah satu ruangan hotel yang ada di Banjarmasin. Sesi posttest untuk kelompok eksperimen dilakukan setelah kegiatan pelatihan selesai pada Sabtu 22 September 2018 dan untuk kelompok kontrol juga dilakukan pada hari itu. Berdasarkan skoring dari hasil posttest yang dilakukan dengan menggunakan kategorisasi seperti perhitungan pretest, maka didapatkan hasil sebagai berikut:

Tabel 5

Hasil Skor Posttest Tingkat Depresi Kelompok Eksperimen

\begin{tabular}{cccc}
\hline Kelompok & Subjek & Skor pretest & Kategori \\
\hline Eksperimen & $\mathrm{A}$ & 1 & Tidak ada gejala \\
& $\mathrm{B}$ & 8 & Tidak ada gejala \\
& $\mathrm{C}$ & 13 & Depresi Ringan \\
& $\mathrm{D}$ & 6 & Tidak ada gejala \\
& $\mathrm{E}$ & 16 & Depresi Sedang \\
& $\mathrm{F}$ & 14 & Depresi Ringan \\
& $\mathrm{G}$ & 0 & Tidak ada gejala \\
& $\mathrm{H}$ & 14 & Depresi Ringan \\
& $\mathrm{I}$ & 15 & Depresi Ringan \\
& $\mathrm{J}$ & 15 & Depresi Ringan \\
\hline
\end{tabular}

Dari tabel 5 dapat diketahui skor posttest kelompok eksperimen. Skor terendah 0 dan skor tertinggi 16. Dari 10 subjek terdapat 4 orang yang menunjukkan tidak ada gejala depresi, 
kemudian ada 5 orang yang berada pada kategori depresi ringan dan ada 1 orang yang berada pada kategori depresi sedang.

Tabel 6

Hasil Skor Posttest Tingkat Depresi Kelompok Kontrol

\begin{tabular}{cccc}
\hline Kelompok & Subjek & Skor posttest & Kategori \\
\hline Kontrol & $\mathrm{K}$ & 17 & Depresi Sedang \\
& $\mathrm{L}$ & 27 & Depresi Berat \\
& $\mathrm{M}$ & 8 & Tidak ada gejala \\
& $\mathrm{N}$ & 5 & Tidak ada gejala \\
& $\mathrm{O}$ & 8 & Tidak ada gejala \\
& $\mathrm{P}$ & 6 & Tidak ada gejala \\
& $\mathrm{Q}$ & 12 & Depresi Ringan \\
& $\mathrm{R}$ & 22 & Depresi Sedang \\
& $\mathrm{S}$ & 5 & Tidak ada gejala \\
& $\mathrm{T}$ & 19 & Depresi Sedang \\
\hline
\end{tabular}

Dari tabel 6 dapat diketahui skor posttest kelompok kontrol. Skor terendah 5 dan skor tertinggi 27. Dari 10 subjek ada 5 orang yang menunjukkan tidak ada gejala depresi, kemudian ada 1 orang yang berada pada kategori depresi ringan. Selanjutnya, ada 3 orang yang berada pada kategori depresi sedang dan ada 1 orang yang berada pada kategori depresi berat.

\section{Analisis Data}

Analisa data dilakukan dengan cara mendeskripsikan atau menggambarkan data yang diperoleh sebagaimana adanya tanpa bermaksud membuat kesimpulan atau generalisasi. Berikut adalah hasil skor pretest, postest dan wawancara tingkat depresi pada kelompok eksperimen:

Tabel 7

Deskripsi Statistik Subjek Penelitian

\begin{tabular}{ccccc}
\hline & \multicolumn{2}{c}{ Kelompok Eksperimen } & \multicolumn{2}{c}{ Kelompok Kontrol } \\
\hline & Pretest & Posttest & Pretest & Posttest \\
$\mathrm{N}$ & 10 & 10 & 10 & 10 \\
$\mathrm{SD}$ & 3,69534 & 6,03324 & 4,69042 & 7,86624 \\
Mean & 17,1 & 10,2 & 14 & 12,9 \\
\hline
\end{tabular}




\begin{tabular}{llccc}
\hline Minimum & 12 & 0 & 10 & 5 \\
Maximum & 22 & 16 & 24 & 27 \\
\hline
\end{tabular}

Analisis data skor kelompok eksperimen menunjukkan ada penurunan rata-rata sebesar $6,9$ Pretest $=17,1$ dan posttest $=10,2)$. Sedangkan analisis data skor kelompok kontrol menunjukan suatu penurunan rata-rata yang relatif kecil yaitu 1,1 (Pretest $=14$ dan posttest $=$ $12,9)$.

Analisis data yang digunakan untuk menguji hipotesis dalam penelitian ini adalah uji Mann-Whitney, berdasarkan table 7 pada pengukuran pretest kelompok eksperimen memperoleh skor terendah 12 dan tertinggi 22 dengan rerata 17.1. Sedangkan kelompok kontrol memperoleh skor terendah 10 dan skor tertinggi 24 dengan rerata 14. Pada pengukuran posttest kelompok eksperimen memperoleh skor terendah 0 dan skor tertinggi 16 dengan rerata 10.2. Sedangkan kelompok kontrol memperoleh skor terendah 5 dan skor tertinggi 27 dengan rerata 12.9.

Tabel 8

Uji Mann-whitney kelompok eksperimen antara pengukuran pretest dan posttest

\begin{tabular}{cc}
\hline Mann-Whitney & 15.000 \\
Wilcoxon W & 70.000 \\
Z & -2.666 \\
Asymp. Sig (2-tailed) & .008 \\
Exact Sig. [2*(1-tailed Sig.)] & .007 \\
\hline
\end{tabular}

Berdasarkan tabel 8 , terlihat bahwa taraf signifikansi depresi pada mahasiswa adalah 0,008 $(\mathrm{p}<0,05)$ sehingga dapat disimpulkan bahwa terdapat perbedaan rerata skor depresi pada mahasiswa kelompok eksperimen pada pengukuran pretest dan posttest. Hal ini menunjukkan bahwa sebelum dan setelah diberikan intervensi, kelompok eksperimen mengalami penurunan tingkat depresi yang signifikan. 
Tabel 9

Uji Mann-Whitney kelompok kontrol antara pengukuran pretest dan posttest

\begin{tabular}{cc}
\hline Mann-Whitney & 40.000 \\
Wilcoxon W & 95.000 \\
Z & -.758 \\
Asymp. Sig (2-tailed) & .448 \\
Exact Sig. [2*(1-tailed Sig.)] & .481 \\
\hline
\end{tabular}

Berdasarkan tabel 9, terlihat bahwa taraf signifikansi depresi pada mahasiswa kelompok kontrol adalah $0.448(\mathrm{p}>0,05)$ sehingga dapat disimpulkan bahwa tidak terdapat perbedaan rerata skor depresi pada mahasiswa kelompok kontrol pada pengukuran pretest dan posttest. Hal ini menunjukkan bahwa sebelum dan setelah diberikan intervensi, kelompok kontrol memiliki tingkat depresi yang sama.

Tabel 10

Uji Mann-whitney hasil pretest antara kelompok eksperimen dan kelompok control

\begin{tabular}{cc}
\hline Mann-Whitney & 24.500 \\
Wilcoxon W & 79.500 \\
$\mathrm{Z}$ & -.1 .942 \\
Asymp. Sig (2-tailed) & .052 \\
Exact Sig. [2*(1-tailed Sig.)] & .052 \\
\hline
\end{tabular}

Berdasarkan tabel 10, terlihat bahwa taraf signifikansi hasil pretest kelompok eksperimen dan kelompok kontrol adalah 0,052 ( $>00,05)$ sehingga dapat disimpulkan bahwa tidak terdapat perbedaan rerata skor pretest antara kelompok eksperimen dan kelompok kontrol. Hal ini menunjukkan bahwa sebelum diberikan intervensi, kedua kelompok penelitian memiliki tingkat depresi yang sama. 
Tabel 11

Uji Mann-whitney hasil posttest antara kelompok eksperimen dan kelompok control

\begin{tabular}{cc}
\hline Mann-Whitney & 42.500 \\
Wilcoxon W & 97.500 \\
Z & -.569 \\
Asymp. Sig (2-tailed) & .570 \\
Exact Sig. [2*(1-tailed Sig.)] & .570 \\
\hline
\end{tabular}

Berdasarkan tabel 11, terlihat bahwa taraf signifikansi hasil posttest kelompok eksperimen dan kelompok kontrol adalah 0,570 ( $>00,05)$ sehingga dapat disimpulkan bahwa tidak terdapat perbedaan rerata skor posttest antara kelompok ekspreimen dan kelompok kontrol. Hal ini menunjukkan bahwa setelah diberikan intervensi, kedua kelompok penelitian memiliki tingkat depresi yang sama.

Hasil analisis menunjukkan bahwa masing-masing kelompok memiliki tingkat depresi yang sama dan setelah diberikan intervensi, tingkat depresi pada mahasiswa tidak mengalami perubahan namun rerata skor pada masing-masing kelompok penelitian mengalami penurunan. Untuk mengetahui apakah penurunan tersebut akibat dari pemberian intervensi berupa Konseling Qur'ani, maka perlu dilakukan analisis lebih lanjut dengan mengolah gain score yang merupakan selisih skor pretest dan posttest subjek penelitian.

Berdasarkan data gain skore subjek pada kelompok eksperimen dan kelompok kontrol diketahui bahwa:

Tabel 12

Deskripsi data gain score

\begin{tabular}{cccccc}
\hline \multicolumn{2}{c}{ Kelompok Eksperimen } & \multicolumn{3}{c}{ Kelompok Kontrol } \\
\hline Skor pretest & Skor posttest & Gain score & Skor pretest & Skor posttest & Gain score \\
\hline 12 & 1 & 11 & 11 & 17 & -6 \\
13 & 8 & 5 & 16 & 27 & -11 \\
22 & 13 & 9 & 24 & 8 & 16 \\
16 & 6 & 10 & 12 & 5 & 7 \\
16 & 16 & 0 & 12 & 8 & 4 \\
22 & 14 & 8 & 10 & 6 & 4 \\
\hline
\end{tabular}




\begin{tabular}{cccccc}
\hline 15 & 0 & 15 & 20 & 12 & 8 \\
17 & 14 & 3 & 14 & 22 & -8 \\
22 & 15 & 7 & 10 & 5 & 5 \\
16 & 15 & 1 & 11 & 19 & -8 \\
\hline
\end{tabular}

Tabel 13

Statistic deskriptif gain score

\begin{tabular}{llllll}
\hline Kelompok & $\mathrm{N}$ & Min. & Max. & Rerata & Standar Deviasi \\
Eksperimen & 10 & 0 & 15 & 6.90 & 4.701 \\
Kontrol & 10 & -11 & 16 & 1.10 & 8.812 \\
\hline
\end{tabular}

Berdasarkan tabel 13 dapat diketahui bahwa pada kelompok eksperimen memperoleh gain score dengan skor terendah 0 dan tertinggi 15 dengan rerata 6,90. Sedangkan pada kelompok kontrol memperoleh gain score dengan skor terendah -11 dan skor tertinggi 16 dengan rerata 1,10 .

Tabel 14

Uji Mann-Whitney hasil gain score antara kelompok eksperimen dan kelompok control

\begin{tabular}{cc}
\hline Mann-Whitney & 42.500 \\
Wilcoxon W & 97.500 \\
Z & -.569 \\
Asymp. Sig (2-tailed) & .570 \\
Exact Sig. [2*(1-tailed Sig.)] & .570 \\
\hline
\end{tabular}

Hasil uji Mann-whitney terhadap gain score depresi pada mahasiswa menunjukkan bahwa tidak terdapat perbedaan yang signifikan $(Z=-1,553 ; p>0,05)$ antara kelompok eksperimen dan kelompok kontrol. Hal ini menunjukkan bahwa tidak adanya perbedaan tingkat depresi pada mahasiswa antara kelompok eksperimen dan kelompok kontrol setelah diberikan intervensi.

\section{Pembahasan}

Penelitian ini bertujuan untuk mengetahui perbedaan antara kelompok eksperimen yang diberikan intervensi dan kelompok konrtol yang tidak diberikan intervensi konseling 
Qur'ani serta untuk mengetahui bagaimana efektivitas intervensi konseling Qur'ani. Berdasarkan hasil penelitian diketahui bahwa hipotesis yang berbunyi “Adanya perbedaan yang signifikan antara kelompok eksperimen setelah diberikan intervensi konseling Qur'ani dan kelompok kontrol yang tidak diberikan intervensi" secara statistik tidak terbukti atau ditolak karena $Z=-0,569$ Sig. 0,570 ( $>0$,05). Setelah diketahui hasil hipotesis tersebut, kemudian dilakukan pula analisis lebih lanjut untuk meyakinkan hasil uji hipotesis pertama, maka diperoleh hasil analisis dengan nilai $Z=-1,553$ Sig. 0,121 ( $p>0,05)$. Artinya tidak ada perbedaan signifikan tingkat depresi pada mahasiswa antara kelompok eksperimen setelah diberikan intervensi dan kelompok kontrol yang tidak diberikan intervensi.

Secara analisis statistik hipotesis ditolak. Hal ini juga dipengaruhi oleh berbagai faktor baik dari subjek maupun peneliti dalam mengikuti kegiatan konseling Qur'ani. Namun bukan berarti konseling Qur'ani tidak memberikan dampak atau manfaat kepada subjek. Karena meskipun begitu terbukti dari hasil uji Mann-Whitney pada kelompok eksperimen pretest dan posttest bahwa terdapat penurunan tingkat depresi yang signifikan dari sebelum dan sesudah diberikan intervensi dengan $Z=-2,666$ Sig. 0,008 ( $p<0,05)$.

Dalam rangka mengetahui efektifitas pelatihan konseling Qur'ani, peneliti melakukan analisa lanjutan. Yakni analisis uji Wilcoxon skor post test dan Wawancara pada kelompok eksperimen. Diperoleh skor $Z=-0,609$ a dan skor $p=0,542$ sehingga $p>0,05$. Berdasarkan analisis uji Wilcoxon tersebut diketahui bahwa konseling Qur'ani dapat dikatakan efektif untuk menurunkan tingkat depresi pada mahasiswa.

Ada beberapa hal yang menyebabkan uji statistik tidak signifikan, antara lain ukuran sampel kecil, prasyarat analisis yang tidak dipatuhi, pengaruh variabel intervening. Serta penyebab-penyebab lainnya seperti tidak seriusnya subjek pada saat pelatihan konseling Qur'ani atau kondisi subjek yang sedang tidak dalam kondisi sehat pada saat mengikuti pelatihan.

Selain itu, ada pula hal lain yang menyebabkan tidak signifikannya nilai uji statistik. Pada penelitian Ningsih dinyatakan adanya pengaruh variabel intervening juga mempengaruhi hasil uji statistik dengan adanya variabel moderator, pada penelitian ini cara mengatasi masalah, penerimaan diri, dan kepribadaian subjek menjadi variabel moderator. Konseling 
Qur'ani akan mempengaruhi cara mengatasi masalah subjek dan penerimaan diri serta kepribadian subjek menjadi variabel moderator.

Konseling Qur'ani akan mempengaruhi cara mengatasi masalah subjek dan penerimaan diri sebelum memberi berpengaruh terhadap kesejahteraan subjektif, selain itu kepribadian juga merupakan salah satu faktor yang mempengaruhi tingkat depresi pada seseorang. Selain itu, faktor pengganggu validitas internal juga mempengaruhi hasil uji yang tidak signifikan, ada beberapa faktor yang menjadi pengganggu validitas internal menurut Campbell dan Stanley yaitu: pengalaman, maturasi, proses pengujian, seleksi subjek penelitian, subjek yang dibuang dan difusi atau imitasi intervensi.

Pada penelitian ini faktor yang dianggap peneliti sebagai pengganggu validitas internal adalah pengalaman dan maturase seperti yang dikatakan Ross dan Morrison bahwa faktor pengalaman dan kejadian masa lampau yang berbeda-beda menyebabkan individu memiliki cara pandang yang berbeda juga terhadap suatu hal, dan ini dapat mempengaruhi validitas penelitian eksperimental yang disebabkan oleh adanya interaksi antar individu. Demikian pula pada penelitian ini diketahui bahwa faktor pengalaman bermakna interaksi antar subjek pada masa lampau ataupun salama jeda saat intervensi di luar kendali peneliti. Seperti intervensi subjek dengan teman-temannya yang berpengaruh pada kondisi dan mood subjek.

Fakor lainnya yang dapat mengganggu validitas internal adalah maturasi. Maturasi merupakan proses yang menimbulkan perubahan pada subjek. Perubahan-perubahan yang dimaksud adalah perubahan yang tidak berhubungan dengan variabel tergantung yang diperhatikan oleh peneliti. Faktor maturasi meliputi perubahan-perubahan sistematis dalam suatu waktu yang meliputi perubahan fisik dan kejiwaan. Faktor maturasi sering terjadi pada penelitian jangka panjang, dimana faktor biologis maupun psikologis dapat mempengaruhi variabel tergantung subjek, dan bisa diatasi dengan menggunakan kelompok kontrol. Penelitian ini menggunakan kelompok kontrol sebagai kelompok pembanding untuk meminimalisir gangguan faktor maturase. Namun, menurut hasil wawancara yang dilakukan dapat diketahui bahwa ada beberapa hal yang mungkin dapat mengganggu proses pelatihan seperti kondisi fisik yang kelelahan, kesehatan, kondisi mood yang tidak stabil, dan tingkat 
fokus serta keseriusan saat mengikuti pelatihan konseling Qur'ani. Hal ini diketahui dari hasil wawancara terhadap narasumber mengenai subjek yang berada pada kelompok eksperimen.

Meskipun hasil analisis tidak signifikan namun intervensi yang dilakukan memberikan dampak yang variatif terhadap subjek eksperimen. Hal ini dapat dilihat dari pelaksanaan wawancara yang dilakukan oleh narasumber beberapa saat setelah pelatihan konseling Qur'ani dilakukan. Pada saat pelaksanaan wawancara subjek mengungkapkan bahwa kondisi fisik dan mood yang tidak stabil membuat beberapa di antara mereka kurang serius mengikuti pelatihan konseling Qur'ani.

Di sisi lain pada kelompok kontrol ditemukan hal serupa pada penelitian yang dilakukan oleh Herawati dan Himam menyatakan bahwa selama rentang waktu tertentu ada faktor-faktor yang dapat mempengaruhi hasil penelitian. Penelitian eksperimen kuasi ternyata memiliki hal-hal yang dapat mengancam validitas internal, yaitu sejauh mana intervensi dapat menyebabkan perubahan pada variabel tergantung. Dari hasil analisis dapat diketahui bahwa dalam proses penelitian seluruh peristiwa yang terjadi selama rentang awal intervensi sampai dengan pengukuran posttest yang dapat mempengaruhi efek dari intervensi yang diberikan dan maturitas adalah perubahan alami yang dialami oleh partisipan penelitian yang muncul bahkan tanpa adanya intervensi. Demikian halnya pada kelompok kontrol dalam penelitian ini, penurunan tingkat depresi yang terjadi tanpa pemberian intervensi dikarenakan perubahan secara alami seperti adanya kegiatan positif yang diikuti oleh subjek kelompok kontrol yang diadakan pihak Universitas. Lingkungan perguruan tinggi yang mendukung terjadinya perubahan individu menjadi religius dan adaptif sehingga dapat menurunkan tingkat depresi pada mahasiswa.

Setelah sesi wawancara berakhir, didapatkan keterangan bahwa semua peserta atau subjek dapat merasakan dampak dari pelatihan konseling Qur'ani yang diberikan. Subjek pelatihan mengakui bahwa setelah mengikuti pelatihan konseling Qur'ani mereka menjadi lebih tenang serta mengetahui apa yang harus mereka lakukan pada saat itu terkait dengan masalah yang sedang mereka hadapi. Beberapa dari subjek pelatihan bahkan ada yang langsung mempraktekkan penyelesaian masalah berdasarkan insight yang didapatkan ketika 
pelatihan konseling Qur'ani selesai, hal ini subjek ungkapkan pada saat mengikuti sesi wawancara.

Pelatihan konseling Qur'ani juga menyadarkan mereka tentang tujuan hidup yang sedang mereka jalani dan tujuan mereka untuk hidup di dunia ini. Mereka menyadari bahwa tujuan mereka hidup di dunia ini adalah untuk menyembah Allah Swt dan untuk beribadah, serta segala sesuatu yang ada di dunia ini sudah diatur oleh Allah Swt. kemudian, mereka juga menyadari bahwa segala permasalahan yang mereka hadapi tidak lain merupakan cobaan yang diberikan oleh Allah untuk mengetahui tingkat ketaqwaan mereka dan apakah mereka akan mengembalikan segala permasalahan pada Al-Qur'an sebagai kitab pedoman umat Islam.

Depresi merupakan suatu perasaan kesedihan yang psikopatologis, disertai perasaan yang sedih, kehilangan minat dan kegembiraan, berkurangnya energi yang menuju kepada meningkatnya keadan mudah lelah yang sangat nyata sesudah bekerja sedikit saja dan berkurangnya aktivitas yang bisa jadi menandakan adanya gangguan kesehatan.

Gejala klinis depresi dapat terlihat sebagai salah satu bentuk gangguan kejiwaan pada alam perasaan yang ditandai dengan kemurungan, kelesuan, ketiadaan gairah hidup, perasaan tidak berguna, putus ada, kesedihan yang mendalam dan lain sebagainya. Gejala fisik dari depresi juga bisa dilihat secara umum, salah satunya adalah kelelahan, merasa sakit fisik, merasa lelah dan mereka mungkin merasa sulit tertidur dan mungkin sering terbangun (Davison, Neale, \& Hindman, 1996).

Hal-hal dapat menyebabkan depresi menurut Keltner ada beberapa faktor, diantaranya faktor biologi, faktor genetik dan faktor psikososial. Ketiga faktor tersebut dapat mempengaruhi satu sama lain. Contoh penyebab depresi dari faktor biologis misalnya karena sakit, pengaruh hormonal, depresi pasca melahirkan, penurunan berat yang drastis sedangkan penyebab depresi yang berasal dari faktor psikososial bisa berupa konflik individual atau interpersonal, masalah eksistensi, masalah kepribadian, dan masalah keluarga.

Jika gejala-gejala depresi sudah mulai terlihat pada diri individu, maka individu yang mengalami depresi harus mendapatkan penanganan segera. Jika dibiarkan lebih lanjut akan memicu perilaku tindakan bunuh diri. Salah satu penanganan depresi ialah melalui konseling. 
Konseling merupakan proses bantuan penyelesaian masalah, bersifat terbuka dengan bertemu muka yang diberikan oleh tenaga profesional.

Konseling adalah proses memberikan kesempatan kepada klien untuk mengeksplorasi, menemukan dan menjelaskan cara hidup yang lebih memuaskan dan cerdas dalam menghadapi sesuatu. Konseling mengindikasikan hubungan professional antara konselor terlatih dengan klien. Hubungan ini biasanya bersifat individu ke individu, tetapi terkadang juga melibatkan lebih dari satu orang. Konseling didesain untuk menolong klien dalam memahami dan menjelaskan pandangan mereka, mengenal kehidupan dan untuk membantu mencapai tujuan penentuan diri (self determination) melalui pilihan yang telah di informasikan dengan baik dan bermakna bagi mereka, serta melalui pemecahan masalah emosional atau karakter personal.

Konseling memiliki sejarah panjang dan telah teruji sebagai terapi untuk orang yang mengalami depresi. Konseling adalah salah satu intervensi yang efektif dari kondisi depresi bila dibandingkan pengobatan depresi dengan menggunakan obat. Konseling dapat membantu seseorang untuk mengatasi permasalahannya, hal penting yang harus dilakukan adalah mencari sumber permasalahan. Konseling yang bersifat spiritual Islami sebagai sebuah harapan baru dalam membangun kembali mental dan jiwa umat manusia yang telah rapuh. Pencarian sumber permasalahan dalam rangka menemukan solusi dapat dilakukan dengan berpedoman pada Firman Allah Swt dalam Al-Qur'an. Seperti yang telah dijelaskan juga dalam Al-Qur'an surah An-Nahl ayat 89 yang menjelaskan bahwa Al-Qur'an merupakan petunjuk, rahmat, dan sumber kegembiraan bagi umat. Hal ini diperkuat lagi dalam surah Yunus ayat 57 yang mengungkapkan hal serupa. Selain sebagai petunjuk, rahmat, serta sumber kebahagiaan AlQur'an juga diturunkan sebagai As-Syifa bagi orang yang beriman yaitu obat bagi segala penyakit hati. Dengan demikian dapat disimpulkan bahwa Al-Qur'an memang merupakan solusi dari segala permasalahan yang terjadi di dalam kehidupan ini.

Sebagai salah satu media komunikasi Allah Swt kepada manusia, Al-Qur'an merupakan kitab pedoman yang paling lengkap bahkan sangat memahami eksistensi manusia di dunia ini. Al-Qur'an juga menjelaskan tentang makna dan tujuan kehidupan manusia selama berada di dunia ini, yaitu untuk beribadah, untuk menghadapi ujian, untuk meraih kehidupan akhirat 
yang lebih baik dan menyadari bahwa dunia ini besifat sementara. Berdasarkan paparan yang telah diberikan maka peneliti merancang sebuah model intervensi menggunakan pendekatan integrasi Ilmu Psikologi dan Islam yaitu konseling Qur'ani. Konseling dengan pendekatan Islam menggunakan getar iman (daya rohaniah) dalam mengatasi problem kejiwaan. Oleh karena itu, maka terapi sabar, tawakkal, ikhlas, sadaqah, ridla, cinta, ibadah, zikir, jihad dan lain-lainnya pasti dapat digunakan sesuai dengan masalahnya. Salah satu konseling Islami yang juga dapat digunakan sebagai media untuk mengatasi problem kejiwaan adalah Konseling Qur'ani.

Konseling Qur'ani adalah proses konseling dengan berpedoman pada Firman Allah Swt dalam Al-Qur-an. Konseling Alqurani juga dapat diartikan sebagai upaya membantu individu belajar mengembangkan fitrah dan atau kembali kepada fitrah, dengan cara memberdayakan (empowering) iman, dan kemauan yang dikaruniakan Allah Swt kepadanya untuk mempelajari tuntunan Allah dan Rasul-Nya, agar fitrah yang ada pada individu itu berkembang dengan benar dan kokoh sesuai tuntunan Allah Swt. Dalam Al-Qur'an terdapat banyak kandungan nilai seperti tentang keimanan, ibadah, ilmu pengetahuan, tentang kisah-kisah tertentu, filsafat, dan juga ada sebagai tata hubungan manusia sebagai makhluk individu maupun makhluk sosial. Kandungan dalam Al-Qur'an dapat diharapkan menjadi motivasi dan penyemangat bagi mahasiswa yang mengalami depresi yang sedang putus asa.

Konseling dapat diterima secara luas sebagai bentuk pertolongan yang sesuai untuk beragam masalah atau perhatian personal, yang paling umum adalah depresi, kegelisahan, kesedihan, kesulitan menjalin hubungan, krisis dan trauma kehidupan, kecanduan, perilaku rendah diri dan ambisi yang dipangkas. Telah disebutkan bahawa konseling bisa dilakukan untuk menolong depresi pada seseorang. Konseling yang dalam hal ini digunakan adalah konseling dengan pendekatan Islami yaitu Konseling Qur'ani.

Konseling Qur'ani adalah proses konseling dengan mengambil rujukan utama Firman Allah Swt di dalam Al-Qur'an. Konseling ini merupakan salah satu aplikasi dari konseling berdasarkan paradigma Psikologi Islami yang lebih dikenal sebelumnya dengan istilah "Konseling Islami”. 
Konseling Qur'ani dalam penelitian ini merupakan kegiatan penggalian emosi, identifikasi permasalahan diri dan proses penyelesaian permasalahan dengan menggunakan Al-Qur'an. Penumbuhan keyakinan bahwa segala permasalahan dapat diselesaikan melalui AlQur'an. Al-Qur'andianggap sebagai terapi yang sangat utama, karena di dalamnya memuat resep-resep mujarab yang dapat menyembuhkan penyakit jiwa manusia. Al-Qur'an diinginkan untuk tidak hanya dimaknai sebagai sebuah kitab suci, tetapi juga sebuah kitab yang isinya terwujud atau berusaha diwujudkan dalam kehidupan sehari-hari. Pada pelatihan konseling Qur'ani ini subjek dilatih untuk mengendalikan emosi dan menerima apa yang telah terjadi dikehidupan sehari-hari dengan terus sabar tawakal dan terus menggunakan Al-Qur'ansebagai pedoman dalam menyelesaikan permasalahan sehari-hari, dan hal ini terbukti dari menurunnya tingkat depresi yang dialami oleh kelompok eksperimen.

Depresi biasanya terjadi saat stress yang dialami oleh seseorang tidak kunjung reda dan depresi yang dialami berkorelasi dengan kejadian dramatis yang baru saja terjadi atau menimpa seseorang. Hal-hal yang dapat menyebabkan mahasiswa mengalami depresi dari hasil konseling individu yang dilakukan diketahui bahawa sebagian besar mereka tidak mampu mengendalikan emosi dengan baik, dan dipengaruhi oleh faktor-faktor biologis dan psikososial lainnya juga. Seperti, sakit, pengaruh hormonal, konflik dengan teman, masalah keluarga, organisasi dan lain sebaginya. Dari hasil penelitian ini dapat diketahui bahwa salah satu hal yang dapat menurunkan tingkat depresi individu adalah dengan cara melakukan konseling Qur'ani.

Peserta konseling Qur'ani mengatakan bahwa peserta mendapatkan pencerahan dan metode baru dalam mencari pemecahan masalah dalam kehidupan, yakni dengan menggunakan Al-Qur'an. Sesuai dengan yang ditulis oleh Sukirno bahwa di dalam Al-Qur'an banyak menceritakan kisah-kisah konseling baik yang dilakukan oleh para nabi dan rasulnya maupun yang diwahyukan langsung oleh Allah Swt. kepada Nabi Muhammad Saw sebagai solusi atas permasalahan-permasalahan yang dihadapi umatnya.

Salah satu dampak yang ditimbulkan dalam realitas kehidupan manusia masa kini adalah munculnya berbagai gangguan psikologis seperti depresi. Gangguan depresi ini terjadi akibat adanya suatu kesedihan yang sangat mendalam, gangguan mood atau hal lainnya. 
Perasaan tersebut muncul karena kecewa mengalami situasi yang sama sekali tak terduga dan tak diharapkan terjadi dalam hidupnya. Ada beberapa alternatif penanganan yang dapat dilakukan untuk mengatasi gangguan ini, salah satunya dengan konseling, dalam penelitian ini yaitu konseling Qur'ani yaitu konseling yang dapat menjadi solusi alternatif lainnya dalam menangani gangguan depresi. Hal ini mengacu kepada fungsi dari Al-Qur'an itu sendiri. AlQur'an diturunkan Allah kepada Nabi Muhammad Saw., untuk segenap umat manusia. Dalam Al-Qur'an termaktub ayat-ayat yang mengupas sifat penciptaan manusia, menerangkan tentang jiwa manusia, penyakit jiwa, menerangkan penyebab-penyebab penyimpangan penyakit jiwa serta metode pendidikan dan penyembuhan jiwa. Sehingga al-Qur'an bisa sebagai petunjuk untuk memahami tabiat manusia sekaligus sebagai pengobat atau terapi jiwa manusia.

\section{Kesimpulan}

Berdasarkan analisis data dan pembahasan diatas, secara umum menunjukkan bahwa tidak terdapat perbedaan yang signifikan antara kelompok eksperimen setelah diberikan intervensi konseling Qur'ani dan kelompok kontrol yang tidak diberikan intervensi. Hasil penelitian menunjukkan kelompok eksperimen mengalami penurunan tingkat depresi yang signifikan sedangkan pada kelompok kontrol menunjukkan hasil yang sama dari pretest dan posttest yakni memiliki tingkat depresi yang sama. Secara analisis statistik, hipotesis tidak terbukti namun bukan berarti konseling Qur'ani tidak memberikan dampak atau manfaat kepada subjek. Hal ini juga dipengruhi oleh berbagai faktor baik dari subjek maupun peneliti dalam mengikuti kegiatan konseling Qur'ani yang membuat hipotesis penelitian ditolak. Kemudian dari analisis uji Wilcoxon tersebut diketahui bahwa konseling Qur'ani dapat dikatakan efektif untuk menurunkan tingkat depresi pada mahasiswa, dan tidak menunjukkan kenaikan tingkat depresi pada mahasiswa meskipun konseling Qur'ani telah diberikan lebih dari dua minggu. Hasil analisis deskriptif kualitatif menunjukkan hal yang sama, bahwa semua peserta atau subjek dapat merasakan dampak dari pelatihan konseling Qur'ani yang diberikan. Subjek pelatihan mengakui bahwa setelah mengikuti pelatihan konseling Qur'ani mereka menjadi lebih tenang serta mengetahui apa yang harus mereka lakukan pada saat itu terkait 
dengan masalah yang sedang mereka hadapi. Beberapa dari subjek pelatihan bahkan ada yang langsung mempraktekkan penyelesaian masalah berdasarkan insight yang didapatkan ketika pelatihan konseling Qur'ani selesai.

Saran

Peneliti selanjutnya, untuk peneliti selanjutnya diharapkan mengupayakan true eksperimen agar mendapatkan hasil penelitian eksperimen yang lebih baik.

\section{Referensi}

Adz-Dzakiey, H. B. (2006). Prophetic intelligence: kecerdasan kenabian: mengembangkan potensi robbani melalui peningkatan kesehatan ruhani. Pustaka Al-Furqan.

American Psychiatric Association. (2000). Diagnostic and Statistical Manual of Mental Disorder. Washington: American Psychiatric Association.

Aziz, A. (t.t.). Abdul Aziz, Kultur Qur'ani di Era Global, Jurnal Ilmu Alquran dan Tafsir, IAIN Surakarta. Jurnal Ilmu Al Quran dan Tafsir.

Brannon, S. E., \& Nelson, R. O. (1987). Contingency management treatment of outpatient unipolar depression: A comparison of reinforcement and extinction. Journal of consulting and clinical psychology, 55(1), 117.

Budiharto, S., \& Anggraini, R. . (2007, Agustus 4). Survey Efektivitaas Konseling Qur'ani untuk Meningkatkan Kesadaran Diri Mahasiswa. Dipresentasikan pada Temu Ilmiah Dalam Rangka Konfrensi Nasional Psikologi Islam II, Fakultas Psikologi Universitas Islam Sultan Adam.

Creswell, J. W. (2014). Pendekatan Kualitatif, Kuantatif dan Mixed. Yogyakarta: Pustaka Pelajar.

Davison, G. C., Neale, J. M., \& Hindman, D. (1996). Abnormal psychology. New York City: Wiley New York.

Ekayani, S. P. (2018). Efektivitas Konseling Qur'ani Terhadap Kesejahteraan Subjektif Ibu Yang Memiliki Anak Berkebutuhan Khusus (Skripsi). Universitas Islam Indonesia, Yogyakarta.

Hariyanto, A. D. (2010). Prevalensi depresi dan faktor yang mem-pengaruhi pada mahasiswa Fakultas Kedokteran Univer-sitas Katolik Atmajaya angkatan 2007. Jakarta: Karya Tulis Ilmiah Kedokteran.

Hawari, D. (2010). Psikopatologi Bunuh Diri. Jakarta: Balai Penerbit FK UI.

Larastiti, A. P., Fitrikasari, A., \& AS, W. S. (2014). Hubungan Tingkat Depresi dengan Perilaku Masturbasi pada Mahasiswa Fakultas Kedokteran Tahun Pertama. Jurnal Kedokteran Diponegoro, 3(1).

Moh, N. (2011). Metode Penelitian. Bogor: Ghalia Indonesia.

Morrison, J. (1995). DSM-IV made easy. New York City: The Guilford Press.

Najati, M. U. (2005). Psikologi dalam al-Qur'an: Terapi Qur'ani dalam Penyembuhan Gangguan Kejiwaan. Bandung: CV Pustaka Setia. 
Nurmiati, A. (2005). Depresi: Aspek Neurobiology, Diagnosis dan Tatalaksana. Jakarta: Balai Penerbit FK UI.

Sugiyono. (2012). Metode Penelitian Kombinasi (Mixed Methods). Bandung: Alfabeta.

Sugiyono. (2017). Statistika untuk Penelitian. Bandung: Alfabeta.

Yorika, H. (2016). Hubungan Kualitas Tidur Dengan Depresi Pada Mahasiswa Tingkat AKhir Jurusan Teknik Mesin Universitas Andalas Tahun 2016 (Skripsi). Fakultas Teknik Mesin Universitas Andalas, Padang. 